\title{
Effect of Recycled Aggregates on Strength and performance of Recylced Aggregate Concrete
}

\author{
Dr.V. Mallikarjuna Reddy ${ }^{1}$ and M. Manikanta Sai Swaroop $^{2}$ \\ ${ }^{1}$ Professor \&Head, Department of Civil Engineering, Gokaraju Rangaraju Institute of Engineering and Technology, Hyderabad, India. \\ ${ }^{2}$ PG student, Department of Civil Engineering, Gokaraju Rangaraju Institute of Engineering and Technology, Hyderabad, India.
}

\begin{abstract}
This study is taken up to utilise the recycled coarse aggregate and recycled fine aggregate as replacement of natural aggregate in concrete mix. It is required to find the percentage of recycled coarse aggragate and recycled fine aggregate, as the strength of concrete can not be achieved by using higher percentaged. The purpose of study is to compare between recycled coarse aggregate and recycled fine aggregate with natural coarse aggregate and sand in terms of specific gravity, water absorption, particle size distribution. Further, this stydy will also consider the difference between the performance of Recycled Aggregate Concrete for different percentages of recycled coarse aggregate and recycled fine aggregate i.e for $0 \%, 10 \%, 15 \%, 20 \%, 25 \%, 30 \%, 35 \%$ replacement. The present study is an experimental investigation on the behaviour of recycled aggregate concrete (coarse\& fine aggregates) with respect to the strength and performance.
\end{abstract}

\section{Introduction}

The most common material used in the world is water. After water Concrete is the most important construction material used through out the world in different types of civil engineering activities. Day by day scarcity of quality coarse aggrgate and fine aggregate is taking place. Restrictions on mining of aggregates is increasing day by day due to greater awareness of environmental protection. This leads to search for substitute material. It forces to reuse aggregate extracted from the construction and demolition waste (C\&D waste) in new concrete. $\mathrm{C} \& \mathrm{D}$ waste generally contains Concrete rubble as major share. This concrete rubble can be crushed and sorted out for recycled coasre aggregate and fine aggregate. These can be used as a replacement material for natural aggregates in concrete or as a sub-base or a base layer in pavements. The material which is extracted from Construction and Demolition waste and used again in making concrete is called as recycled aggregate. The natural aggregate can be replaced with reused aggregate up to $25 \%$. Beyond this percentaget the strength starts to reduce [1]. Based on the quantity and size of recycled aggregate, a regression model has been modified appropriately by test results[2]. The increase of Recycled aggregate content and $\mathrm{w} / \mathrm{c}$ ratio decreases the durability of concrete [3]. Concrete with acceptable strength and durability can be produced along with high packing density is achieved [4]. The absorption and drying shrinkage of Recycled Aggregate Concrete linearly increase with the increase of replacement percentage of Recycled Aggregate Concrete, but decrease when certain amount of fly ash is mixed in the Recycled Aggregate Concrete [5]. As the age goes on old structures become unserviceable.

\section{Objectives}

$>$ To know the percentage use of recycled aggregates in the construction.

$>$ To know the strength and performance of recycled aggregates and other admixtures.

$>$ To know the performance of recycled aggregate concrete.

\section{Materials}

\section{A. Portland cement}

Cement is tested for its physical peoperties in the laboratory as per the Indian standards. When cement reacts with water it liberates considerable heat and this reaction is termed as exothermic. Due to the reaction Calcium Silicate Hydrates are formed, which are responsible for the good properties of concrete. It is better to use cement produced within three months from the date of production.

Table 1. Physical properties of OPC

\begin{tabular}{|c|c|}
\hline CHARECTERISTICS & OBSERVED VALUE \\
\hline N.C & $34 \%$ \\
\hline IST & $60 \mathrm{mins}$ \\
\hline FST & $260 \mathrm{mins}$ \\
\hline S.G & 3.10 \\
\hline C.S for 28 days & $49.56 \mathrm{Mpa}$ \\
\hline
\end{tabular}

\footnotetext{
* Corresponding author: author@e-mail.org
} 


\section{B. Fine aggregate}

\section{(i) R-Sand}

Ordinary river sand is used. Specimens are casted using the sand passing through $2.36 \mathrm{~mm}$ sieve. As per the methodology mentioned in IS2386 (Part-I)-1963Sieve analysis for the sand is carried out in the laboratory. Sand plays key role in reducing shrinkage of concrete in the process of curing. Sand will also help in reducing the cost. As the availability of sand is becoming scarce, Manufactured sand can be used in making concrete. Recylced fine aggregate can also be used in making concrete. Sand can be tested as per Indian Standards in the laboratory.

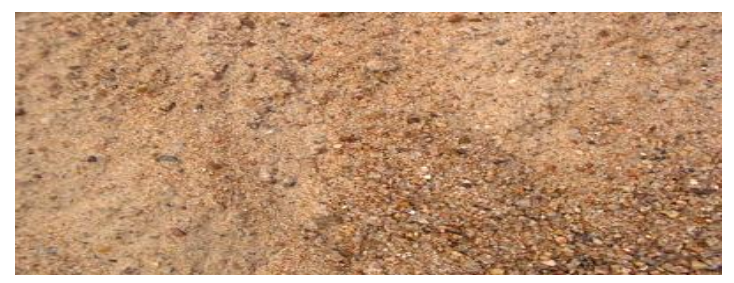

Fig 1 Fine aggregate

Table 2. P.P of fine aggregate

\begin{tabular}{|c|c|}
\hline CHARECTERISTICS & OBSERVATION \\
\hline S.G & 2.75 \\
\hline F.M & 2.25 \\
\hline
\end{tabular}

(ii) Recycled fine aggregate

Recycled fine aggregate is extracted from demolished concrete members. Recycled fine aggregate used in the stydy is $2.36 \mathrm{~mm}$. Quality of recycled aggregate plays vital role in achieving the required strength as they are minimising the voids in the concrete mass. It is useful to make concrete homogeneous. It is to be seived properly before using in the concrete. It should be free from unwanted material.

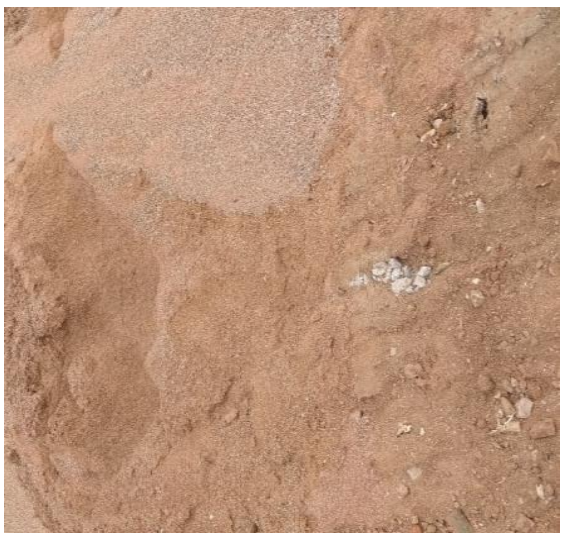

Fig 2 Recycled Fine aggregate

Table 3. P.P of Recycled fine aggregate

\begin{tabular}{|c|c|}
\hline CHARECTERISTICS & OBSERVATION \\
\hline S.G & 2.50 \\
\hline F.M & 4.50 \\
\hline
\end{tabular}

\section{Coarse aggregate}

\section{(i) Fresh crushed coarse aggregate}

The coarse aggregate used in the study is $20 \mathrm{~mm}$ crushed stone. As per IS: 2386-1963 the physical properties are assessed. Coarse aggregate is extracted from different types of Rocks.

Table 4. P.P of coarse aggregate

\begin{tabular}{|c|c|}
\hline CHARECTERISTICS & $\begin{array}{c}\text { OBSERVED } \\
\text { VALUE }\end{array}$ \\
\hline S.G & 2.64 \\
\hline F.M & 5.84 \\
\hline Crushing value & 20.02 \\
\hline Impact value & 18.75 \\
\hline
\end{tabular}

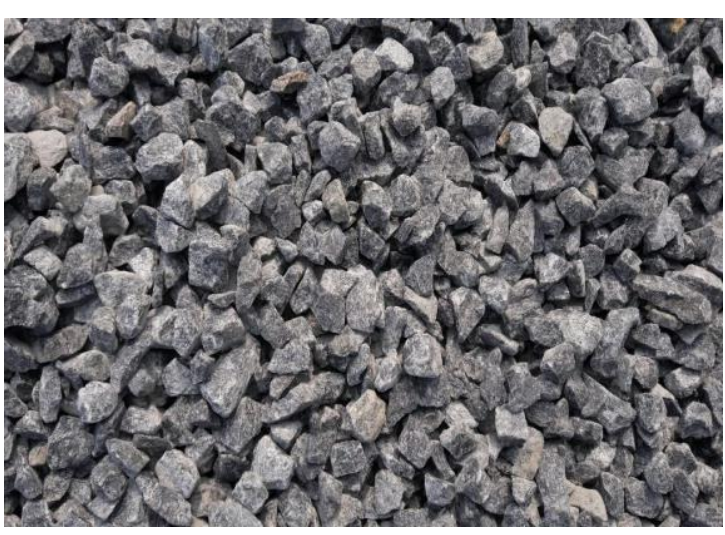

Fig 3 Coarse aggregate

\section{(ii) Recyced Coarse aggregate}

The recycled coarse aggregate used in this stydy is extracted from demolished concrete members after crushing. Recycled coarse aggregate used in the study is of $20 \mathrm{~mm}$ size. Coarse aggregate give body to the mass of concrete. It plays vital role in reducing shrinkage. It also helps in reducing the cost of concrete as we are using waste material. It is tested as per Indian Standards for knowing the physical properties.

Recycled aggregate is classified into the following types. Recycled concrete aggregate (RCA): Aggregate extracted from crushed concrete made with Natural aggregate.

Construction and demolition recycled aggregate (CDRA): Aggregate which has not been properly extracted from construction and demolition waste, or Recycled aggregate that is un recognisable due to a lack of information on its composition.

Table 5. P.P of RCA

\begin{tabular}{|c|c|}
\hline CHARECTERISTICS & $\begin{array}{c}\text { OBSERVED } \\
\text { VALUE }\end{array}$ \\
\hline S.G & 2.75 \\
\hline F.M & 6.58 \\
\hline Crushing value & $40.37 \%$ \\
\hline Impact value & $44.53 \%$ \\
\hline
\end{tabular}




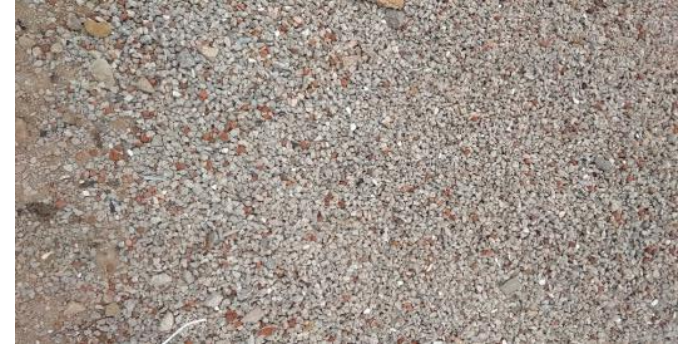

Fig.4. Recycled Aggregate

\section{Experimental Investigation}

\subsection{Concrete design}

Mix for M30 grade is done as per IS10262:2009. The results of concrete mix design are as given below. Concrete mix design is done by knowing the physical properties of different ingredients used in it. Before doing mix design it is required to know the grade of concrete required and degree of workability. Water cement ratio plays vital role.

Table 6. Design Mix for M30 grade concrete

\begin{tabular}{|c|c|}
\hline Grade of concrete & M30 \\
\hline Cement & $362 \mathrm{Kg} / \mathrm{Cum}$ \\
\hline F.A & $682.6 \mathrm{Kg} / \mathrm{Cum}$ \\
\hline C.A & $1184.4 \mathrm{Kg} / \mathrm{Cum}$ \\
\hline Water & $162.9 \mathrm{Kg} / \mathrm{Cum}$ \\
\hline
\end{tabular}

\subsection{Compressive strength test}

The size of cube used to conduct the compression test in accordance with IS 516: 1959 is $100 \mathrm{~mm} \times 100 \mathrm{~mm} \times$ $100 \mathrm{~mm}$. Three samples are used to test the compressive strength at the age of 3, 7, 28 days curing. Cube casted and de-moulded properly. The cubes removed should be cured for 28days as per Indian Standards in potable water.

Table 7 compressive strength $\left(\mathrm{N} / \mathrm{mm}^{2}\right)$ for Recycled aggregate concrete

\begin{tabular}{|c|c|c|c|}
\hline \multirow{2}{*}{ Mix } & \multicolumn{2}{|c|}{ C.S $\left(\mathrm{N} / \mathrm{mm}^{2}\right)$ for_days } & \multirow{2}{*}{$\begin{array}{c}\text { Percentage } \\
\text { decrease in } \\
\text { strength }\end{array}$} \\
\cline { 2 - 3 } & 7 & 28 & - \\
\hline Mix 1(10\%) & 27.2 & 40 & 7.5 \\
\hline Mix 2(15\%) & 25.17 & 37 & 15 \\
\hline Mix 3(20\%) & 23.8 & 34 & 20 \\
\hline Mix 4(25\%) & 22.5 & 32 & 21.5 \\
\hline Mix 5(30\%) & 21.98 & 31.4 & 28.25 \\
\hline Mix 6(35\%) & 19.88 & 28.7 & \\
\hline
\end{tabular}

\subsection{Split Tensile strength test}

The dimensions of cylinder used to conduct the split tensile strength test in accordance with IS 5816: 1999 is $100 \mathrm{~mm} \times 200 \mathrm{~mm}$. Two samples are used to test the split tensile strength test at the age of 7, 28 days curing.

\subsection{Rapid Chloride Permeability Test (RCPT)}

The size of cylinders used to conduct Rapid chloride permeability test is $100 \mathrm{~mm} \times 50 \mathrm{~mm}$. This test is carried out at the age of 28 days. The RCPT test consists of moulds with electrodes, connecting wires and RCPT machine.

\section{Proposed Methodology}

The laboratory work is carried out in to two phases. Basic tests were performed on materials in first phase. Specimens were casted in second phase to assess the performance and strength of concrete. The concrete is prepared by reused coarse aggregate and reused fine aggregate with various percentages i.e $10 \%, 15 \%, 20 \%$, $25 \%, 30 \%$ and $35 \%$ and 0.5 water cement ratio. Workability test on Green concrete was done. C.S, S.T.S tests on Hardened concrete were done after 3, 7 and 28 days of curing. Durability of concrete is assessed by using Rapid Chloride test.

\section{Results and Discussions}

From the results it is observed that when the percentage of replacement of Natural aggregate with reccylced coarse aggregate goes on increasing the strength decrease. At 10 percent replacement compressive strength is $40 \mathrm{MPa}$. At 15 percent replacement compressive strength is $37 \mathrm{MPa}$. There is decrease in compressive strength by $7.5 \%$. At 20 percent replacement the compressive strength is $34 \mathrm{MPa}$.There is a decrese in compressive strength by $15 \%$. At 25 percent replacement the compressive strength is $32 \mathrm{MPa}$. There is a decrease in compressive strength by $20 \%$. At 30 percent replacement the compressive strength is $31.4 \mathrm{MPa}$. There is a decrease in compressive strength by $21.5 \%$. At $35 \%$ replacement the compressive strength is $28.7 \mathrm{MPa}$. There is a decrease in compressive strength by $28.25 \%$. Based on the results wecan replace upto $30 \%$. Beyond that required compressive strength is not achieved. If the aggregates are segregated properly required strength can be achieved for higher percentages of replacement. Type of stone fromwhich aggregate is extracted is also important.

\section{Outcomes Expected}

It is estimated that the recycled aggregates beyond the limits will decreases the workability and strength of concrete. Shape and size of aggregate will affect the strength of the concrete greatly. Further it is estimated that the voids in the concrete will reduce due to reused fine aggregate and increases the strength. Use of recycled aggregate makes concrete economical.

\section{References}

1. L Satyanarayana, S Sudhakara Rao "Role of recycled coarse aggregate in concrete". IJARSE, volume-07, issue-06, (2018). 
2. Ma Kang and Li Weibin "Effect of the aggregate size on strength properties of recycled aggregate concrete". AMSE, volume-2, (2018).

3. Hui Guo, Caijun Shi, Xuemao Guan, Jianping Zhu, Yahong Ding "Durability of recycled aggregate concrete-A review". Cement and concrete composite 89, 251-259, (2018).

4. Anchula Nagarjuna, T. Suresh Kumar, B.Yogeswara Reddy, M.Udaykiran, International Journal of Innovative Technology and Exploring Engineering, Vol. 8 no. 11, pp: 640-645, (2019)

5. Sherif Yehia, Kareem Helal et. Al "Strength and durability evaluation of recycled aggregate concrete". International journal of concrete structures and materials, volume-09, issue-02, (2015).

6. Jianzhuang Xiao, Deng $\mathrm{Lu}$ and Jingwei Ying "Durability of recycled aggregate concrete". Journal of Advanced Concrete Technology, volume11, 347-359, (2013).

7. Mallikarjuna Reddy, V., Praveen, R. Effect of polyethylene glycol in self-curing of self compacting concrete. International Journal of Recent Technology and Engineering, 8(3), pp. 72807283, (2019)

8. Tummala Suresh Kumar, Kosaraju Satyanarayana, Materials Today: Proceeding, 26 (2), 3228-3233, (2020)

9. Mallikarjuna Reddy, V., Vasanthi, S. Effect of elevated temperatures on fiber reinforced self compacting concrete. International Journal of Recent Technology and Engineering, 8(3), pp. 77757778, (2019)

10. Mallikarjuna Reddy, V., Bhaskar, B. Mechanical behaviour of self compacting concrete by using Msand \& rice husk ash, 8(10), pp. 3320-3323, (2019) 